\title{
A case study of GM maize gene flow in South Africa
}

Chris Viljoen $^{1 * \dagger}$, Lukeshni Chetty ${ }^{2+}$

\begin{abstract}
Background: South Africa has been growing first-generation commercial genetically modified (GM) maize since 1997. Despite a requirement for non-GM food, especially for export, there is no system for coexistence of GM and non-GM crop. Gene flow is a major contributor to commingling, and different distances of cross-pollination have been recorded for maize, using a variety of field-trial designs under different environmental conditions, with the furthest distance being $650 \mathrm{~m}$. However, these trials have usually been small plots and not on the scale of commercial farming. There are also no published data regarding the extent of cross-pollination for maize in South Africa, even after a decade of commercialization of GM. Thus, the aim of this study, conducted from 2005 to 2007, was to determine the extent of GM maize cross-pollination under South African conditions in the context of commercial farming practice.

Materials and methods: Field trials were planted with a central plot of yellow GM maize (0.0576 ha) surrounded by white non-GM maize (13.76 ha), in two different geographic regions over two seasons with temporal and spatial isolations to surrounding commercial maize planting. Cross-pollination from GM to non-GM maize was determined phenotypically across 16 directional transects. Pollen counts during flowering were compared to weather data as well as percentage cross-pollination. The data were transformed logarithmically, and mean percentage cross-pollination was compared to high cross-pollination.

Results and discussion: Although there was a general congruency between wind data, pollen load and crosspollination, it is evident that wind data and pollen load do not solely explain the directional extent of crosspollination and that swirling winds may have contributed to this incongruence. Based on the logarithmic equations of cross-pollination over distance, $45 \mathrm{~m}$ is sufficient to minimize cross-pollination to between $<1.0 \%$ and $0.1 \%, 145 \mathrm{~m}$ for $<0.1 \%$ to $0.01 \%$ and $473 \mathrm{~m}$ for $<0.01 \%$ to $0.001 \%$. However, compared to this, a theoretical isolation distance of $135 \mathrm{~m}$ is required to ensure a minimum level of cross-pollination between $<1.0 \%$ and $0.1 \%$, $503 \mathrm{~m}$ for $<0.1 \%$ to $0.01 \%$ and $1.8 \mathrm{~km}$ for $<0.01 \%$ to $0.001 \%$ based on high values of cross-pollination.

Conclusions: Based on the results of this study, the use of mean values of cross-pollination over distance may result in an underestimation of gene flow. Where stringent control of gene flow is required, for example, for nonGM seed production or for GM field trials under contained use, the high values of cross-pollination should be used to determine isolation distance. However, this may not be practical in terms of the isolation distance required. We therefore suggest that temporal and distance isolations be combined, taking into account the GM maize pollen sources within the radius of the most stringent isolation distance required.
\end{abstract}

\footnotetext{
* Correspondence: viljoencd@ufs.ac.za

† Contributed equally

${ }^{1} \mathrm{GMO}$ Testing Facility, Department of Haematology and Cell Biology,

University of the Free State, Bloemfontein, South Africa

Full list of author information is available at the end of the article
}

\section{SpringerOpen ${ }^{\circ}$}

(c) 2011 Viljoen and Chetty; licensee Springer. This is an Open Access article distributed under the terms of the Creative Commons Attribution License (http://creativecommons.org/licenses/by/2.0), which permits unrestricted use, distribution, and reproduction in any medium, provided the original work is properly cited. 


\section{Background}

South Africa is one of the few African countries that have introduced genetically modified (GM) crops. South Africa has been growing first-generation commercial GM crops since 1997 [1]. In 2008, South Africa was ranked eighth in terms of global commercial GM production [2]. It is estimated that $90 \%$ of cotton (insect resistance (IR) and herbicide tolerance (HT)), $80 \%$ of soybean (HT), 72\% of yellow maize (IR and HT) and $55 \%$ of white maize (IR and HT) (an important food staple) productions in South Africa are GM [2]. In 2008/ 2009 , there were 14 field trials of various GM crops in South Africa [3]. Thus, it is expected that the number of approved GM events grown in South Africa will increase in the future.

Despite more than a decade of rapid adoption of GM crops in South Africa, there is currently no emphasis on coexistence to establish management practices for the effective segregation between GM and non-GM crops. Despite this, there is a requirement for non-GM in terms of export commodities, especially to countries in Africa, Asia and Europe. Furthermore, there is an expectation that second- and, especially, third-generation GM crops will become a reality within the next few years. This in itself will necessitate measures for coexistence wherever such crops are grown [4].

In a document published by the European Commission, coexistence is explained as, "the choice of consumers and farmers between conventional, organic and GM crop production, in compliance with the legal obligations for labelling defined in Community legislation. The possibility of adventitious presence of GM crops in non-GM crops cannot be excluded. Therefore, suitable measures are needed during cultivation, harvest, transport, storage and processing to ensure coexistence" [5]. Thus coexistence has become an important issue in managing the introduction of GM crops, especially, since in recent years, there have been several examples of unwanted commingling. Examples of these include the detection of transgenes in landraces in Mexico [6], the introgression of herbicide tolerance in wild bentgrass in the USA [7], the Prodigene pharmaceutical producing maize that commingled with soybean and maize [8], Starlink maize detected in processed food products in 2001 [9] and LibertyLink601 rice found in conventional rice in 2006 [10]. Thus, we suggest that in a broader context, coexistence deals with measures to prevent commingling between GM and non-GM crops in order to minimize economic losses as well as the negative impacts on human health, trade and the environment [11-15]. Thus, unless GM producing countries take steps to ensure coexistence, unwanted commingling of GM and non-GM crop will occur.
One of the considerations of coexistence is the transfer of genes from one population to another through gene flow via pollen [16]. The methods used to study gene flow include potential pollen-mediated gene flow (which includes the analysis of pollen viability, pollen dispersal and deposition, pollen capture and computer modelling) [17-26] and pollen-mediated gene flow (which involves determining the extent of cross-pollination over distance and computer modelling) [27-38]. While several studies have determined the extent of cross-pollination at different distances ranging from 34 to $650 \mathrm{~m}$, it is not certain how applicable these data are to the maize growing region of South Africa. Thus, while the aim of these studies has been to predict theoretical distances in order to minimize gene flow, the varying trial design and environmental conditions make it difficult to extrapolate this information from one region to another. Thus, the aim of this study, conducted from 2005 to 2007, was to determine the extent of GM maize cross-pollination to non-GM maize under South African conditions in the context of commercial farming practice.

\section{Materials and methods \\ Field trial}

Converted MON810 yellow maize hybrids containing Cry1Ab (PAN 6994B or PAN 6724B) and a conventional white maize hybrid (PAN 6479) were planted in two typical commercial maize growing regions, Bainsvlei and Kroonstad during 2005/2006 and Bainsvlei and Waterbron during 2006/2007, situated in the Free State province, South Africa. The hybrids were selected based on their flowering synchronicity (74 to 76 days) and the trials planted according to standard farming practice without any herbicide or insecticide spraying. The trial design consisted of a central yellow GM donor maize field (approximately $20 \times 35 \mathrm{~m}$ ) surrounded by receptor conventional white maize (approximately $180 \times 230 \mathrm{~m}$ for Bainsvlei and Kroonstad and approximately $180 \times$ $800 \mathrm{~m}$ at Waterbron) (Figure 1). The trials were planted with a 4-week temporal isolation to other maize within a $3-\mathrm{km}$ radius to other maize plantings in the area. Weather data (wind speed, wind direction, temperature and relative humidity) were captured (5 days during flowering) using a mobile weather station (Vantage Pro, Davis Instruments Corp., Hayward, CA, USA) and data logger positioned in the centre of the GM plot.

\section{Pollen capture}

Pollen traps were set for 5 days during the flowering period to coincide with weather data. The traps were set at $50 \mathrm{~m}$ intervals from the GM plot in four compass directions (N, S, W and E) up to $400 \mathrm{~m}$. The pollen trap comprised a clamp on a pole with a glass slide coated with 


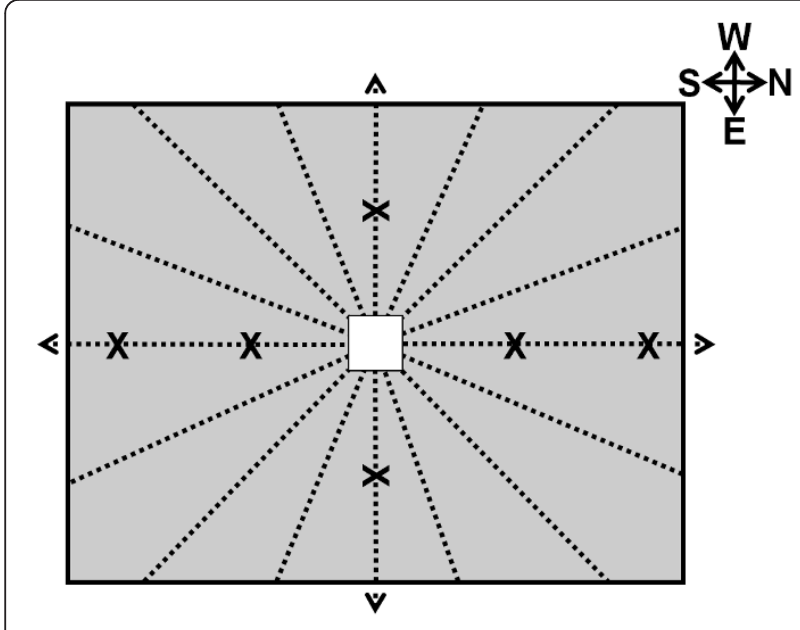

Figure 1 Field layout for Bainsvlei 2005/2006 and 2006/2007 and Waterbron $\mathbf{2 0 0 6 / 2 0 0 7}$. Field layout drawn to scale for Bainsvlei 2005/2006 and 2006/2007 (180 × $230 \mathrm{~m})$ and Waterbron 2006/2007 (180 × $800 \mathrm{~m})$. The open centre block represents the donor yellow GM maize and the surrounding grey block the recipient white non-GM maize. Cobs were collected along the 16 transects every $2 \mathrm{~m}$ up to $100 \mathrm{~m}$ and a further $200 \mathrm{~m}$ at $10 \mathrm{~m}$ intervals at Waterbron as indicated by the dashed line. Pollen traps (indicated by $X$ within the non-GM maize field) were set at $50 \mathrm{~m}$ intervals in four directions and continued up to $400 \mathrm{~m}$.

Tween20, adjusted to a height of $1.8 \mathrm{~m}$ to match the height of flowering maize. The glass slides were placed in the clamp at 6:00 a.m. and removed at 3:30 p.m. daily, for 5 days. Pollen was retrieved from the slides by rinsing them with $1 \mathrm{ml}$ cetyltrimethylammonium bromide (CTAB) buffer $(20 \mathrm{~g} / \mathrm{l} \mathrm{CTAB}, 1.4 \mathrm{M} \mathrm{NaCl}, 0.1 \mathrm{M}$ Tris/ $\mathrm{HCl}$ and $20 \mathrm{mM}$ EDTA, pH 8), after which, it was stored at $4{ }^{\circ} \mathrm{C}$. Pollen was diluted (1:10) and counted using a haemocytometer using a light microscope under $10 \times$ magnification.

\section{Evaluation of cross-pollination}

At seed maturity, the white non-GM field was divided into 16 compass transects and the first cob on the maize plant sampled at $2 \mathrm{~m}$ intervals up to $100 \mathrm{~m}$ at Bansvlei and Waterbron and $10 \mathrm{~m}$ intervals thereafter at Waterbron (Figure 1). A total of 800 cobs were sampled at Bainsvlei and 1,280 at Waterbron, per site per season, respectively.

\section{Statistical analysis and graphical representation}

All the seeds were removed from the cob, and the number of yellow seeds per cob was counted and expressed as a percentage to total seed number per cob. The mean percentage cross-pollination over distance from the GM plot, for all trial sites, was represented graphically and subjected to a power trend line. Each data set was transformed logarithmically and subjected to a linear trend line. The mean crosspollination over distance per location per year was compared to the combined means over all data sets. The logarithmic high values of cross-pollination (the highest value of cross-pollination at a particular distance interval irrespective of direction) over logarithmic distance per location per year were compared to the combined values over all data sets. Theoretical values of cross-pollination were calculated at $1.0 \%$, $0.1 \%, 0.01 \%$ and $0.001 \%$ using linear equations derived from logarithmic cross-pollination over logarithmic distance. ANOVA was performed using Excel 2007 (Microsoft Corporation, Redmond, WA, USA) on theoretical cross-pollination distances derived from logarithmic combined mean cross-pollination over distance compared to logarithmic high cross-pollination over distance. The datasets were combined and the theoretical cross-pollination distances re-calculated using means with a 90\%, 95\% and 99\% confidence interval, respectively.

\section{Results and discussion}

In a comparison of wind, pollen load and crosspollination roses (Figure 2), it is evident that at Bainsvlei $2005 / 2006$, the greatest pollen load over the 5 days of pollen capture was to the west and north, which partially coincides with the greatest incidence of easterly but not northerly wind. However, the greatest incidence of cross-pollination was in a southerly direction. A similar lack of congruency between the direction of wind, pollen load and cross-pollination was observed in Bainsvlei 2006/2007 and Waterbron 2006/2007. In Bainsvlei 2006/2007, the majority of winds were northerly, while the greatest amount of pollen captured was in a northerly and westerly direction and the majority of cross-pollination was again in a southerly direction. Compared to this, Waterbron 2006/2007 had mostly south-easterly and west-north-westerly winds; the greatest pollen load was in an easterly direction with the highest incidence of cross-pollination in a southerly and, secondarily, in a northerly direction. Thus, from these data, it is evident that wind direction, pollen load and the extent of cross-pollination were not in agreement across the different trial sites of this study. The reasons for this are unknown, but we hypothesise that other factors, including wind type, and other environmental and reproductive considerations may play an important role in the effect of pollen load on the extent of cross-pollination. The temperature $\left(18^{\circ} \mathrm{C}\right.$ to $\left.23^{\circ} \mathrm{C}\right)$ and relative humidity ( $29 \%$ to $72 \%$ ) at all three sites were characterized as, during pollen shed, conducive to maintaining maximum pollen viability. Furthermore, all three sites are characterized by swirling winds, and with an influence of primarily northerly winds may partially explain the bias for cross-pollination to the south. This is an important consideration, and most modelling of 


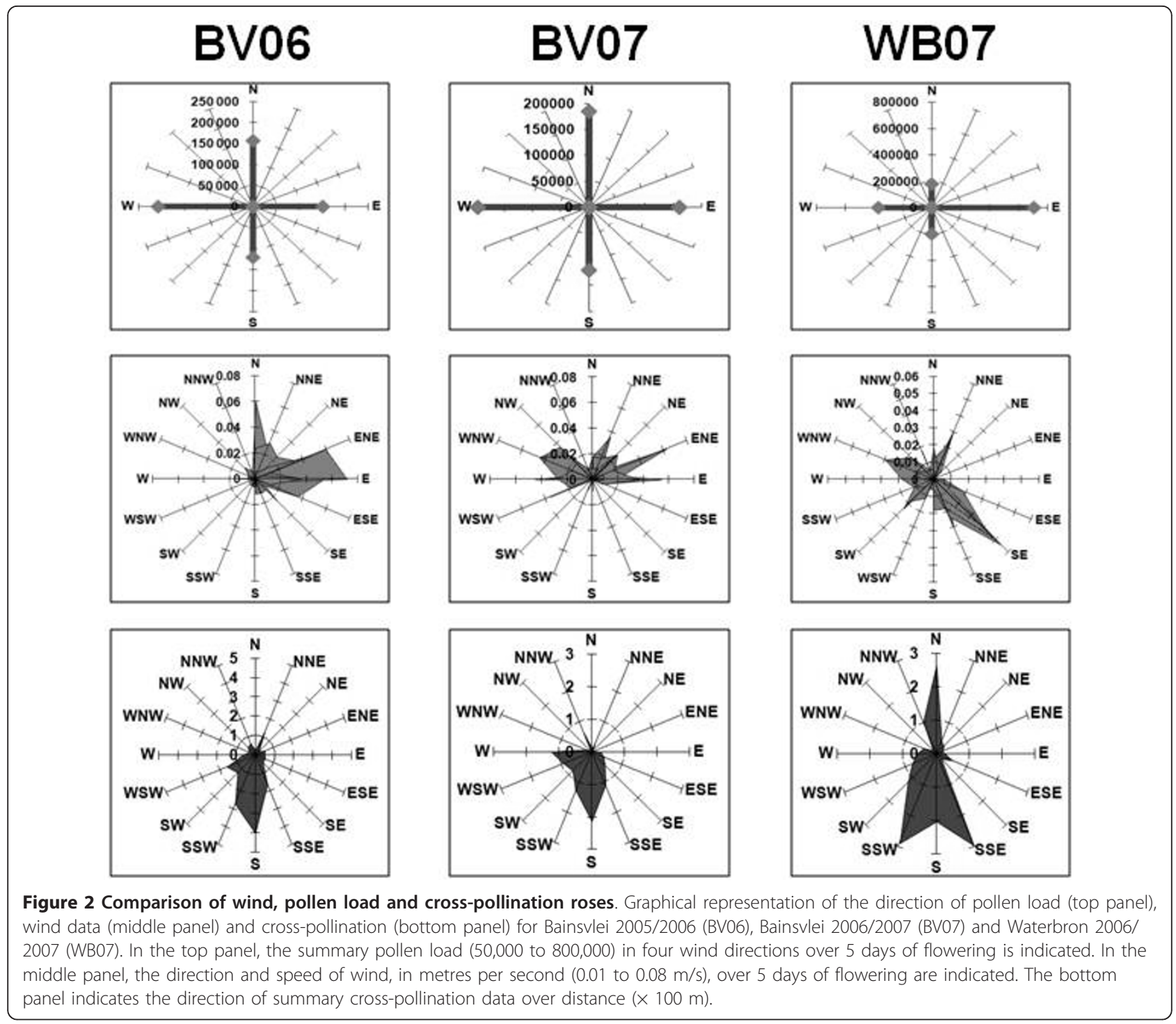

pollen movement and cross-pollination has hitherto assumed that the predominant direction for pollen movement would also translate into the greatest directional degree of cross-pollination [20]. The results from all three trial sites (the Kroonstad trial was terminated due to early frost) suggest that this is not the case for the geographic locations at which the trials occurred in this study.

In this study, similar results to other studies were found regarding the trend in cross-pollination over distance [33-36]. The highest extent of cross-pollination was observed at $2 \mathrm{~m}$ for Bainsvlei 2005/2006 (mean, 14\%; highest, 55\%), Bainsvlei 2006/2007 (mean, 19\%; highest, 54\%) and Waterbron 2006/2007 (mean, 19\%; highest, 82\%) (Figure 3). At all sites, cross-pollination declined sharply up to between 20 and $25 \mathrm{~m}$, after which, followed a plateau of low-percentage cross- pollination up to $100 \mathrm{~m}$ at Bainsvlei and $300 \mathrm{~m}$ at Waterbron, the furthest evaluation point, respectively. Although $98 \%$ of pollen deposition is known to occur within 25 to $50 \mathrm{~m}$ from the source [39], and the extent of cross-pollination is greatly reduced thereafter, it is incorrect to assume that the plateau of low levels of cross-pollination will no longer be observed at or beyond $300 \mathrm{~m}$ [33]. One requirement in establishing isolation distances regarding GM crops is whether cross-pollination should be minimized to below a predetermined threshold, as in the case of non-GM or organic production (depending on the regulations of the region or country), or prevented, as in the case of GM field trials under contained use or pharmaceutical, industrial or biofuel production in food crops, where there is $0 \%$ tolerance for contamination of non-GM food crops. Furthermore, it should be noted that while 


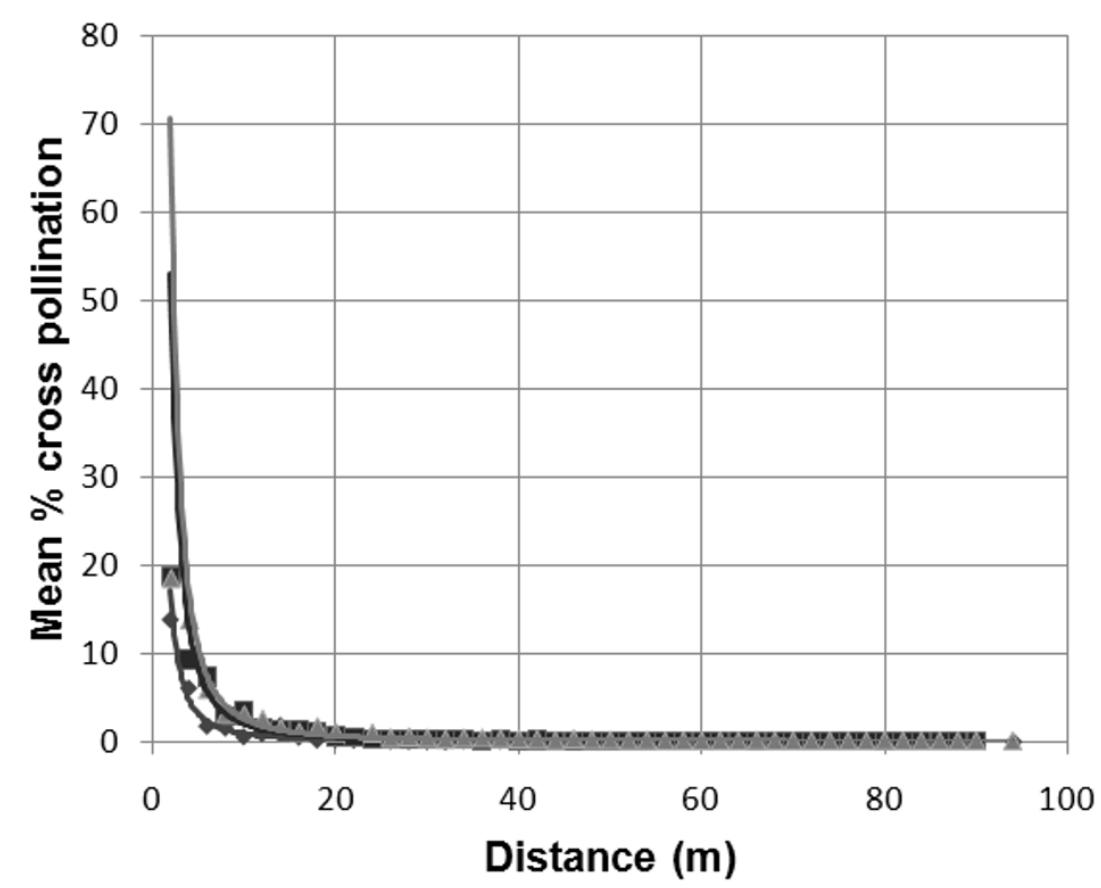

Figure 3 Mean percentage cross-pollination versus distance. Graphical representation of percentage cross-pollination over distance for Bainsvlei 2005/2006 $\left(R^{2}=0.90 ; y=61.043 x^{-1.842}\right)$, Bainsvlei 2006/2007 $\left(R^{2}=0.92 ; y=216.91 x^{-2.036}\right)$ and Waterbron 2006/2007 $\left(R^{2}=0.91 ; y=\right.$ $\left.293.52 x^{-2.055}\right)$ superimposed by power trend lines with $R^{2}$ and equation as indicated.

isolation distance is an important consideration for minimizing gene flow, other factors should also be considered in an integrated risk management plan for GM field trials [40-44].

Logarithmic transformation of the cross-pollination data revealed a linear correlation between mean crosspollination over distance at individual sites (data not provided) as well as combined data over all three sites
(Figure 4). From the linear equation, theoretical isolation distances were calculated to achieve a range of between $<1.0 \%$ and $0.1 \%,<0.1 \%$ and $0.01 \%$ and $<0.01 \%$ and $0.001 \%$ cross-pollination (Table 1). Based on these data, $45 \mathrm{~m}$ is sufficient to minimize cross-pollination to between $<1.0 \%$ and $0.1 \%, 145 \mathrm{~m}$ for $<0.1 \%$ to $0.01 \%$ and $473 \mathrm{~m}$ for $<0.01 \%$ to $0.001 \%$. However, an important consideration of using mean cross-pollination over

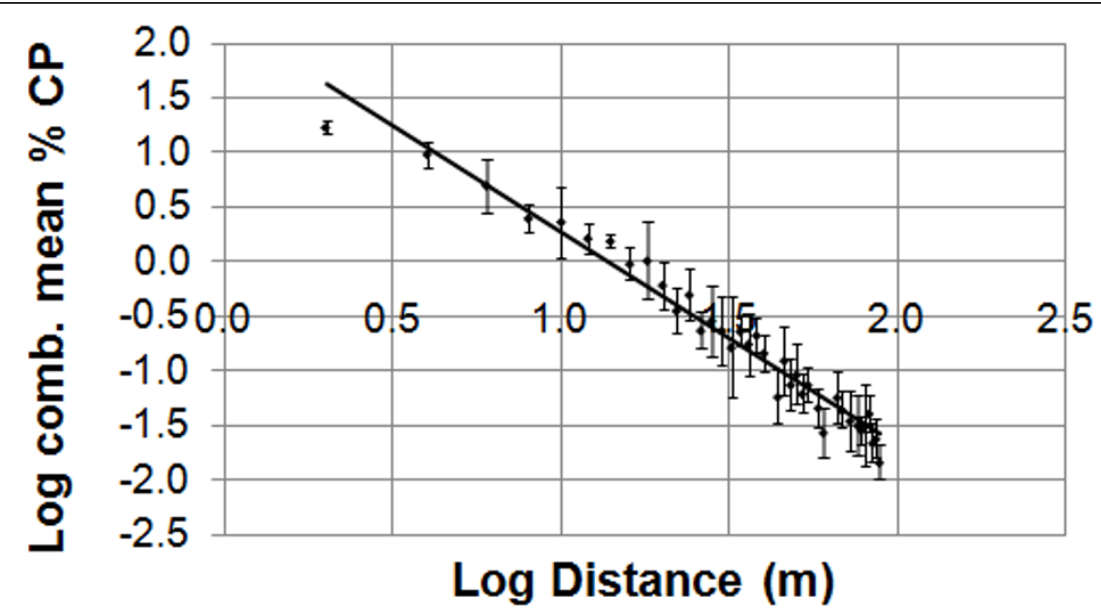

Figure 4 Correlation between logarithmic combined mean percentage cross-pollination and logarithmic distance. Linear correlation of logarithmic combined mean percentage cross-pollination (CP) over distance for all three trial sites $\left(R^{2}=0.87 ; y=-1.9509 x+2.2181\right)$. The vertical error bars on data points represent the standard error of the mean. 
Table 1 Theoretical isolation distances derived from $1.0 \%, 0.1 \%, 0.01 \%$ and $0.001 \%$ cross-pollination

\begin{tabular}{|c|c|c|c|c|c|c|c|c|c|c|c|}
\hline $\begin{array}{l}\text { Percentage } \\
\text { cross- } \\
\text { pollination }\end{array}$ & $\begin{array}{c}\text { Mean } \\
\text { BV06 }^{\text {a }} \\
(\mathrm{m})\end{array}$ & $\begin{array}{c}\text { Mean } \\
\text { BV07 }^{\text {b }} \\
(\mathrm{m}) \\
\end{array}$ & $\begin{array}{c}\text { Mean } \\
\text { WBO7c }^{c} \\
(\mathrm{~m}) \\
\end{array}$ & $\begin{array}{c}\text { Comb } \\
\text { Meand }^{d} \\
(\mathrm{~m})\end{array}$ & $\begin{array}{c}\text { High } \\
\text { BV06 }^{\text {e }} \\
(\mathrm{m}) \\
\end{array}$ & $\begin{array}{c}\text { High } \\
\text { BVO7 }^{f} \\
(\mathrm{~m}) \\
\end{array}$ & $\begin{array}{c}\text { High } \\
\text { WBO7 }^{g} \\
(\mathrm{~m}) \\
\end{array}$ & $\begin{array}{c}\text { Comb } \\
\text { high }^{\text {h }} \\
(\mathrm{m})\end{array}$ & $\begin{array}{c}\text { Mean }^{\mathrm{i}} \\
(90 \% \mathrm{Cl})^{\mathrm{j}} \\
(\mathrm{m})\end{array}$ & $\begin{array}{c}\text { Mean }^{\mathrm{i}} \\
(95 \% \mathrm{CI})^{\mathrm{k}} \\
(\mathrm{m})\end{array}$ & $\begin{array}{c}\text { Mean }^{\mathrm{i}} \\
(99 \% \mathrm{Cl})^{\mathrm{I}} \\
(\mathrm{m})\end{array}$ \\
\hline 1.0 & 9 & 14 & 16 & 14 & 28 & 34 & 40 & 36 & 20 & 19 & 17 \\
\hline 0.1 & 33 & 42 & 50 & 45 & 122 & 129 & 141 & 135 & 125 & 119 & 110 \\
\hline 0.01 & 114 & 126 & 159 & 145 & 530 & 491 & 494 & 503 & 792 & 759 & 694 \\
\hline 0.001 & 398 & 377 & 501 & 473 & 2298 & 1861 & 1739 & 1869 & 5041 & 4861 & 4386 \\
\hline
\end{tabular}

${ }^{\mathrm{a} B a i n s v l e i} 2005 / 2006\left(R^{2}=0.90 ; y=-1.8422 x+1.7856\right) ;{ }^{\mathrm{b}}$ Bainsvlei $2006 / 2007\left(R^{2}=0.92 ; y=-2.0359 x+2.3363\right) ;{ }^{c} \mathrm{Waterbron} 2006 / 2007\left(R^{2}=0.91 ; y=-2.1033 x+\right.$ 2.5423); ${ }^{d}$ combined mean cross-pollination across all trial sites $\left(R^{2}=0.95 ; y=-1.9509 x+2.2181\right) ;{ }^{e}$ Bainsvlei $2005 / 2006\left(R^{2}=0.80 ; y=-1.5652 x+2.2691\right) ;{ }^{f}$ Bainsvlei $2006 / 2007\left(R^{2}=0.92 ; y=-1.7271 x+2.6474\right) ;{ }^{9}$ Waterbron $2006 / 2007\left(R^{2}=0.91 ; y=-1.8318 x+2.9335\right) ;{ }^{\mathrm{h}}$ combined high cross-pollination across all trial sites $\left(R^{2}=\right.$ $0.97 ; y=-1.7547 x+2.7405)$; ${ }^{i}$ the datasets were combined and the means calculated with a $90 \%, 95 \%$ and $99 \% \mathrm{Cl}$, respectively; ${ }^{j}$ isolation distances derived from means from the combined dataset with a $90 \% \mathrm{Cl}\left(R^{2}=0.92 ; y=-1.2445 x+1.6078\right) ;{ }^{k}$ isolation distances derived from means from the combined data with a $95 \%$ $\mathrm{Cl}\left(R^{2}=0.95 ; y=-1.2401 x+1.5719\right)$; 'isolation distances derived from means from the combined data with a $99 \% \mathrm{Cl}\left(R^{2}=0.96 ; y=-1.2493 x+1.55\right)$. Theoretical isolation distances (metres) are derived from $1.0 \%, 0.1 \%, 0.01 \%$ and $0.001 \%$ cross-pollination using logarithmic equations for mean cross-pollination and combined means over distance compared to high cross-pollination over distance for Bainsvlei 2005/2006 (BV06), Bainsvlei 2006/2007 (BV07) and Waterbron $2006 / 2007$ (BV07) $(P<<0.01)$. The theoretical isolation distances were also calculated after combining the data sets from means with a $90 \%, 95 \%$ and $99 \%$ confidence interval $(\mathrm{Cl})$, respectively.

distance is that the distance required to achieve a specified threshold of cross-pollination may be underestimated. In order to test this hypothesis, we plotted the highest values for cross-pollination over distance on a logarithmic scale. There is a linear correlation of the logarithmic transformation of high values of cross-pollination over distance for individual sites as well as combined data over all three sites (Figure 5). Furthermore, there was a significant difference between theoretical isolation distances calculated using the mean versus high values $(P<<0.01)$ (Table 1$)$. The theoretical isolation distances were also calculated from a combination of all three datasets using different confidence intervals (90\%, 95\% and 99\%) to determine whether the use of high values of cross-pollination would overestimate cross-pollination and result in greater than the required isolation distances. However, it was found that the latter approach did not result in significantly different

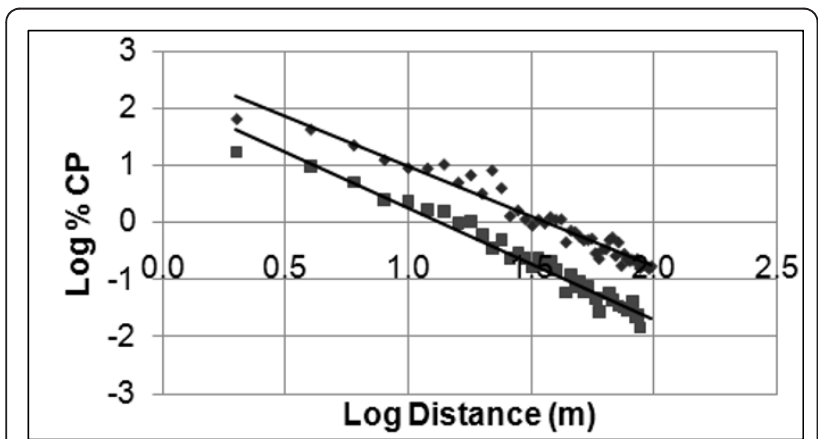

Figure 5 Comparison of percentage mean cross-pollination to percentage high cross-pollination. Linear correlation of logarithmic combined mean percentage cross-pollination (CP) (big squares - lower line) over distance for all three trial sites compared to the linear correlation of logarithmic percentage high crosspollination (small squares - top line) over distance $\left(R^{2}=0.83 ; y=\right.$ $-1.7547 x+2.7405)$. isolation distances compared to the use of high values of cross-pollination $(P>>0.01)$ (Table 1$)$. Thus, we suggest that in order not to underestimate the potential for cross-pollination to occur at a predetermined isolation distance, the high values instead of mean values of cross-pollination over distance should be used. Based on this, a theoretical isolation distance of $135 \mathrm{~m}$ is required to ensure a minimum level of cross-pollination between $<1.0 \%$ and $0.1 \%, 503 \mathrm{~m}$ for $<0.1 \%$ to $0.01 \%$ and $1.8 \mathrm{~km}$ for $<0.01 \%$ to $0.001 \%$. While it may not be required to apply the most stringent isolation distances for non-GM or organic production, it should be a requirement where no commingling can be tolerated, such as GM field trials under contained use or non-GM seed production (Table 2). Furthermore, we recognize that under such conditions, an isolation distance of $1.8 \mathrm{~km}$ to achieve a minimum of $<0.01 \%$ to $0.001 \%$ commingling (the limit of detection for PCR) may not be practical. We therefore suggest the combined use of a 3- to 4-week temporal isolation, which includes all maize fields within a $1.8-\mathrm{km}$ radius of the proposed trial site, with the most practical distance to achieve a $<0.01 \%$ threshold of commingling for GM field trials under contained use. In this study, only one GM pollen source was considered; however, it would be necessary to calculate the potential impact of more than one GM pollen source in a commercial farming environment.

We also observed that there was a shift between the trend lines in Figure 3 for Bainsvlei 2006/2007 and Waterbron 2006/2007 compared to the trend line for Bainsvlei 2005/2006. The graphic representation of mean cross-pollination over distance compared to high cross-pollination over distance produced a similar result (data not shown). Based on this observation as well as the comparison of wind, pollen load and cross-pollination roses, it appears that pollen load and environmental factors on their own are not solely responsible in 
Table 2 Summary of isolation distances based on mean versus high cross-pollination where applicable to non-GM or organic crop production as well as GM field trials and non-GM seed production (X)

\begin{tabular}{|c|c|c|c|}
\hline$\%$ GM threshold & $<1.0$ to 0.1 & $<0.1$ to 0.01 & $<0.01$ to 0.001 \\
\hline Distance range $(\mathrm{m})$ & 14-45 (mean) ${ }^{\mathrm{a}} 36-135$ (high) $^{\mathrm{b}}$ & 45-145 (mean) 135-503 (high) & 145-473 (mean) 503-1869 (high) \\
\hline Non-GM ${ }^{c}$ & $x$ & $x$ & $x$ \\
\hline Organic $^{c}$ & $x$ & $x$ & $x$ \\
\hline GM field trials & & & $x$ \\
\hline Non-GM seed production & & & $x$ \\
\hline
\end{tabular}

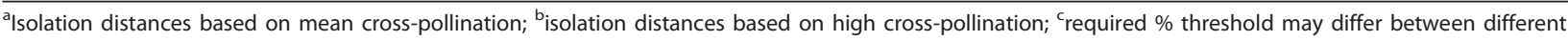
coexistence systems.

determining cross-pollination potential. We hypothesise that reproductive physiological factors are also involved. Although the dynamics of such an interaction is currently unknown, we suggest that cross-pollination is a result of the interaction between pollen load, the environment and reproductive physiology:

Cross-pollination $\leftarrow$ Pollen load $\circ$ Environment $\circ$ Reproductive physiology

\section{Conclusions}

In this study, we have investigated the effect of pollen load and environment on cross-pollination under typical maize growing conditions in South Africa. We have also compared mean cross-pollination to high crosspollination values over distance in order to calculate isolation distances for predetermined thresholds of commingling. Mean cross-pollination data may be sufficient to determine isolation distances where commingling is allowable at a specific threshold, for example, non-GM production. However, to achieve zero commingling for non-GM seed production, or GM field trials under contained use, a more stringent approach through the use of greater isolation distances based on high compared to mean cross-pollination may be required. While this may not be practical under all conditions, it would be possible to achieve maximum stringency through the combined use of temporal and distance isolations, taking into account the GM maize fields within the radius of the most stringent isolation distance required. Finally, comparing the results of this study to others, it is evident that while the overall trends may be similar between different cross-pollination studies, geographic specific data are required to establish isolation distances for a specific region.

\section{Acknowledgements}

We would like to acknowledge funding support from the National Research Foundation and the Centre of Excellence for Invasion Biology, as well as the GMO Testing Facility for providing a research platform and funding. We are grateful to Pannar for advice in seed selection and the use of facilities at Bainsvlei as well as Charl van Deventer for the facilities at Waterbron. We are also thankful to the students associated with the GMO Testing Facility who help with sample collection.

\section{Author details}

${ }^{1} \mathrm{GMO}$ Testing Facility, Department of Haematology and Cell Biology, University of the Free State, Bloemfontein, South Africa ${ }^{2} \mathrm{GMO}$ Monitoring and Research, Applied Biodiversity Research, South African National Biodiversity Institute, Pretoria, South Africa

\section{Authors' contributions}

CV conceived the study and participated in its design and implementation, final data analysis and draft and final manuscript preparation. LC participated in the design of the study, data collection and analysis, primary data analysis and draft manuscript preparation.

\section{Competing interests}

The authors declare that they have no competing interests.

Received: 15 October 2010 Accepted: 24 February 2011

Published: 24 February 2011

References

1. Department of Agriculture: Understanding genetically modified organisms (GMOs). 2005 [http://www.nda.agric.za], accessed 3 October 2005

2. James C: Global status of commercialized biotech/GM crops: 2009. ISAAA Briefs no. 41. Ithaca, NY: International service for the acquisition of Agribiotech applications; 2009.

3. Department of Agriculture, Forestry and Fisheries: Genetically modified organisms Act, 1997. Annual Report 2008/09. 2009 [http://www.nda.agric. za], accessed 4 January 2010.

4. Moschini G: Pharmaceutical and industrial traits in genetically modified crops: coexistence with conventional agriculture. Am J Agr Econ 2006, 88:1184-1192.

5. Europa: Coexistence of genetically modified crops with conventional and organic agriculture. European Commission. 2009 [http://ec.europa.eu/ agriculture/gmo/coexistence/index_en.htm], accessed 21 April 2010.

6. Quist $D$, Chapela IH: Transgenic DNA introgressed into traditional maize landraces in Oaxaca, Mexico. Nature 2001, 414:541-543.

7. Reichman JR, Watrud LS, Lee EH, Burdick CA, Bollman MA, Storm MJ, King GA, Mallory-Smith C: Establishment of transgenic herbicide-resistant creeping bentgrass (Agrostis stolonifera L.) in nonagronomic habitats. Mol Ecol 2006, 15:4243-4255.

8. Elbehri A: Biopharming and the food Systems: examining the potential benefits and risks. AgBioForum 2005, 8:18-25.

9. Segarra $A E$, Rawson JM: Starlink corn controversy: background. CRS report for Congress. 2001 [http://www.nationalaglawcenter.org/assets/crs/ RS20732.pdf], accessed 21 April 2010.

10. FDA: Statement on report of bioengineered rice in the food supply. CFSAN/Office of Food Additive Safety, August 2006. 2006 [http://www. fda.gov/Food/Biotechnology/Announcements/ucm109411.htm], accessed 21 April 2010.

11. Belcher K, Nolan J, Phillips PWB: Genetically modified crops and agricultural landscapes: spatial patterns of contamination. Ecological Economics 2005, 53:387-401. 
12. Brookes $G$, Barfoot $P$, Melé $E$, Messeguer J, Bénétrix F, Bloc D, Foueillassar X, Fabié A, Poeydomenge C: Genetically modified maize: pollen movement and crop coexistence. 2004 [http://www.pgeconomicsco.uk/pdf/ Maizepollennov2004final.pdf], accessed 6 January 2011.

13. Jank B, Rath J, Gaugitsch H: Co-existence of agricultural production systems. Trends in Biotechnology 2006, 24(5):198-200.

14. Moschini $G$, Bulut $H$, Cembalo L: On the segregation of genetically modified, conventional and organic products in European agriculture: a multi-market equilibrium analysis. J Agr Econ 2005, 3:347-372.

15. Schiemann J: Co-existence of genetically modified crops with conventional and organic farming. Environ Biosafety Res 2003, 2:213-217.

16. Huffman WE: Production, identity preservation, labelling in a marketplace with genetically modified and non-genetically modified foods. Plant Physiol 2004, 134:3-10

17. Arritt RW, Clark CA, Goggi AS, Sanchez HL, Westgate ME, Riese JM: Lagrangian numerical simulations of canopy air flow effects on maize pollen dispersal. Field Crop Res 2007, 102:151-162.

18. Aylor DE: Survival of maize (Zea mays) pollen exposed in the atmosphere. Agr Forest Meteorol 2004, 123:125-133.

19. Fonesca AE, Westgate ME, Doyle RT: Application of fluorescence microscopy and image analysis for quantifying dynamics of maize pollen shed. Crop Sci 2002, 42:2201-2206.

20. Fricke BA, Ranjan AK, Bandyopadhyay D, Becker B: Numerical simulation of genetically modified corn pollen flow. The Official Journal of ISPE 2004, 24(3):1-7.

21. Jarosz N, Loubet B, Durand B, McCartney A, Foueillassar X, Huber L: Field measurements of airborne concentration and deposition rate of maize pollen. Agr Forest Meteorol 2003, 119:37-51.

22. Kerhoas C, Gay G, Dumas C: A multidisciplinary approach to the study of the plasma membrane of Zea mays pollen during controlled dehydration. Planta 1987, 171:1-10.

23. Raynor SG, Ogden EC, Hayes JV: Dispersion and deposition from experimental sources. Agron J 1972, 64:420-427.

24. Roy SK, Rahaman SML, Salahuddin ABM: Pollination control in relation to seed yield and effect of temperature on pollen viability of maize (Zea mays L.). Indian J Agric 1995, 65:785-788.

25. Schoper JB, Lambert RJ, Vasilas BL: Pollen viability, pollen shedding, and combining ability for tassel heat tolerance in maize. Crop Sci 1987, 27:27-31.

26. Schoper JB, Lambert RJ, Vasilas BL, Westgate ME: Plant factors controlling seed set in maize. The influence of silk, pollen, and ear-leaf water status and tassel heat treatment at pollination. Plant Physiol 1987, 83:121-125.

27. Aylor DE, Schultes NP, Shields EJ: An aerobiological framework for assessing cross-pollination in maize. Agr Forest Meteorol 2003, 119:111-129.

28. Bannert M, Stamp P: Cross-pollination of maize at long distance. Eur J Agron 2007, 27:44-51.

29. Burris JS: Adventitious pollen intrusion into hybrid maize seed production fields. Proceedings of 56th Annual Corn and Sorghum Research Conference 2001 American Seed Trade Association, Washington, DC; 2001.

30. Byrne PF, Fromherz S: Can GM and non-GM crops coexist? Setting a precedent in Boulder County, Colorado, USA. J Food Agr Environ 2003, 1:258-261

31. Della Porta G, de Ederle D, Bucchini L, Prandi M, Verderio A, Pozzi C: Maize pollen mediated gene flow in the Po valley (Italy): Source-recipient distance and effect of flowering time. Eur J Agron 2008, 28:255-265.

32. Garcia MC, Figueroa JM, Gomez RL, Townsend R, Schoper J: Pollen control during transgenic hybrid maize development in Mexico. Crop Sci 1998, 38:1597-1602

33. Henry C, Morgan D, Weekes R, Daniels R, Boffey C: Farm scale evaluations of GM crops: monitoring gene flow from GM crops to non GM equivalents in the vicinity: Part one forage maize, DEFRA report EPG/1/ 5/138. 2003 [http://www.cib.org.br/estudos/ estudos_cientificos_ambiental_14.pdf], accessed 21 April 2010.

34. Jemison JM, Vayda ME: Cross-pollination from genetically engineered corn: wind transport and seed source. AgBioforum 2001, 4:87-92.

35. Luna SV, Figueroa JM, Baltazar BM, Gomez RL, Townsend R, Schoper JB: Maize pollen longevity and distance isolation requirements for effective pollen control. Crop Sci 2001, 41:1551-1557.
36. Ma BB, Subedi KD, Reid LM: Extent of cross fertilization in maize by pollen from neighbouring transgenic hybrids. Crop Sci 2004, 44:1273-1282.

37. Paterniani $E$, Stort $A C$ : Effective maize pollen dispersal in the field. Euphytica 1974, 23:129-134

38. Stevens WE, Berberich SA, Sheckell PA, Wiltse CC, Halsey Horak MJ, Dunn DJ: Optimizing pollen confinement in maize grown for regulated products. Crop Sci 2004, 44:2146-2153.

39. Eastham K, Sweet J: Genetically modified organisms (GMOs): the significance of gene flow through pollen transfer. Environ Issues Rep 2002, 28:1-75.

40. Andow DA, Zwahlen C: Assessing environmental risks of transgenic plants. Ecol Lett 2006, 9:196-214.

41. Jenczewski E, Ronfort J, Chèvre AM: Crop-to-wild gene flow, introgression and possible fitness effects of transgenes. Environ Biosafety Res 2003, 2:9-24.

42. König A, Cockburn A, Crevel RWR, Debruyne E, Grafstroem R, Hammerling U, Kimber I, Knudsen I, Kuiper HA, Peijnenburg AACM, Penninks AH, Poulsen M, Schauzu M, Wal JM: Assessment of the safety of food derived from genetically modified (GM) crops. Food and Chemical Toxicology 2004, 42:1047-1088.

43. Nap JP, Metz PLJ, Escaler M, Conner AJ: The release of genetically modified crops into the environment. Part I. Overview of current status and regulations. The Plant Journal 2003, 33:1-18.

44. Devos Y, Reheul D, De Schrijver A: The co-existence between transgenic and non-transgenic maize in the European Union: a focus on pollen flow and cross-fertilization. Environ Biosafety Res 2005, 4:71-87.

doi:10.1186/2190-4715-23-8

Cite this article as: Viljoen and Chetty: A case study of GM maize gene flow in South Africa. Environmental Sciences Europe 2011 23:8.

\section{Submit your manuscript to a SpringerOpen ${ }^{\circ}$ journal and benefit from:}

- Convenient online submission

- Rigorous peer review

- Immediate publication on acceptance

- Open access: articles freely available online

- High visibility within the field

- Retaining the copyright to your article

Submit your next manuscript at $>$ springeropen.com 